\title{
Comparison of Reduced $P$ Application and Supplemental Enhancement of Nitrogen (N) and Zinc (Zn) on their Availability and Yield of Rice (Oryza sativa L.) Crop in High- P Soil
}

\author{
Maishnam Anand Singh ${ }^{1 *}$, P. Surendra Babu² and M. Chandini Patnaik ${ }^{2}$ \\ ${ }^{1}$ Department of Soil Science, College of Agriculture, PJTSAU, Rajendranagar, \\ Hyderabad-500030, India \\ ${ }^{2}$ AICRP on Micro \& Secondary Nutrients and Pollutant Elements in Soil and Plants); A.R.I, \\ Rajendranagar, Hyderabad- 500 030, India \\ *Corresponding author
}

\section{A B S T R A C T}

\section{Keywords}

High P soil,

Phosphorus

fixation, RDF,

RDP, P- fertility

Regime, Yield,

Paddy

\section{Article Info}

Accepted:

10 September 2019

Available Online:

10 October 2019
The present investigation entitled "Comparison of Reduced P Application and Supplemental Enhancement of Nitrogen $(\mathrm{N})$ and Zinc (Zn) on their Availability and Yield of Rice Crop (Oryza sativa L.) in High-P Soil" was carried out at AICRP on Micronutrients, Hyderabad Centre, ANGRAU to (i) determine the availability of nitrogen and zinc under different $P$ regimes of the same soil, (ii) to determine whether reducing the $\mathrm{P}$ application or supplementing additional nutrients is a better choice in high- $\mathrm{P}$ soil in terms of yield of paddy crop. A laboratory experiment was conducted after developing low (16), medium (40), high (63), v. high (102) and v.v high (128 kg $\mathrm{P}_{2} \mathrm{O}_{5}$ ha $\left.^{-1}\right)$ soil- $\mathrm{P}$ fertility regimes of a low $\mathrm{P}$ soil using its $\mathrm{P}$ - fixation characteristic curve and by employing 3 levels each of $\mathrm{N}$ and $\mathrm{Zn}$ to determine the availability of these nutrients under different $\mathrm{P}$ - fertility regimes. Net house experiment was conducted employing a high- $\mathrm{P}$ soil $\left(89 \mathrm{~kg}_{2} \mathrm{O}_{5} \mathrm{ha}^{-1}\right)$ using paddy as test crop with two (2) treatments comprising different individual supplementation doses and their combination of $\mathrm{N}$ and $\mathrm{Zn}$ in combination of two levels of $\mathrm{P}$ application (100\% and $70 \% \mathrm{RDP}$ ). Different $\mathrm{P}$-fertility regimes were made using $\mathrm{P}$ - fixation characteristic curve. Under laboratory condition, the availability of $\mathrm{N}$ and $\mathrm{Zn}$ increased with increasing levels of their applications, irrespective of soil $\mathrm{P}$ fertility regimes in 45 days of contact period. Likewise, the availability of $\mathrm{N}$ increased with the increase in contact period from 15 to 45 days. However, in case of zinc the availability decreased as the contact period in the soil increased from 15 to 30 days and there after increased by $45^{\text {th }}$ day of incubation. Under laboratory condition the nitrogen availability increased from 219 to $314 \mathrm{~kg} \mathrm{~N} \mathrm{ha}^{-1}$ in the same soil as the P- fertility regime shifted from low to v.v high thereby registering a 43 per cent enhancement. The available DTPA- Zn extraction decreased by 22 per cent (from 3.28 to $2.55 \mathrm{mg} \mathrm{kg}^{-1}$ ) as the available soil P increased from $16 \mathrm{~kg}$ (low P-regime) to $128 \mathrm{~kg} \mathrm{P}_{2} \mathrm{O}_{5}$ ha $^{-1}$ (v.v high P-regime) of the same soil. The Net house experiment results revealed that additional application of nutrients like $\mathrm{N}$ and $\mathrm{Zn}$ and their combination beyond their current recommended levels enhanced the yield of paddy in a high $\mathrm{P}$ soil. Reduced level of $\mathrm{P}$ application (i.e. supply of $70 \%$ RDP only) to paddy crop decreased its grain yield over supplemental nutrients' treatments in this high-P soil experiment when compared to that of full supply of $100 \%$ recommended dose of $\mathrm{P}$ indicating that additional supply of $\mathrm{N}$ augment the yield of paddy crop in a high-P soil but not when the $\mathrm{P}$ supply is reduced on such soil. The choice between reducing the $\mathrm{P}$ fertilizer in a high- $\mathrm{P}$ soil without affecting the yield and realization of enhanced yield with addition of supplemental doses of nutrients will depend upon whether the reduction in input cost is priority or improving the productivity with little more expenditure. 


\section{Introduction}

The importance of phosphorus in crop production, their behavior in soil and its interrelation with other nutrients in soils and plants is well documented. The use efficiency of applied P fertilizer seldom exceeds 20 to 25 per cent and most of the applied phosphorus is fixed. The continuous use of $P$ fertilizer in the crop production results in gradual enhancement in its availability over years (Nambiar, 1994). The general perception of Indian soils' available P being low to medium status has changed over years due to continuous, increased and discriminate use of $P$ fertilizers. The recent soil fertility mapping undertaken by Department of Agriculture and Co-operation through IISS, Bhopal indicated such paradigm shift in the available P status of Indian soils. Recent studies of AICRP on Soil Test Crop Response (STCR), Hyderabad center revealed that $67 \%$ of 5736 soil samples analyzed from 10 districts of Andhra Pradesh were found to be high in available phosphorus status (Reddy et al., 2013). The occurrence of $\mathrm{P}$ accumulated soils or high- $\mathrm{P}$ soils offer the following opportunities/ constrains in crop production.

Possible saving of $\mathrm{P}$ fertilizer from current recommended doses without affecting the yields of crops

Ability of such soils to provide current yield levels of yield with continued application of reduced amount of $P$

Interference in availability (reduction/ enhancement) of other nutrients availability in soils.

Therefore, it is essential to understand the consequences of occurrence of $\mathrm{P}$ accumulated soils in terms of extent of saving of $\mathrm{P}$ fertilizer, duration upto which $P$ fertilizer can be reduced on such soils, the kind of nutrient interactions and possible environmental pollution (Eutrophication). A decade long experiment conducted by Radio Tracer Laboratory (RTL), ANGRAU revealed that the $\mathrm{P}$ application can be reduced to an extent of 25 to 50 per cent from the current recommended dose of fertilizer in high- $\mathrm{P}$ soils without affecting the yields of crops like rice, maize and sunflower (Annual Report of RTL, 2008- 2010). The interrelationship of $P$ with other nutrients for their availability in soils and uptake was studied for several crops in the past but not in high- $\mathrm{P}$ soils. The Liebig's law of minimum indicated that the yield of crops is limited by most limiting factor (nutrient). However, it is not known that which element/ nutrient would be limiting if $\mathrm{P}$ accumulation increases in soil. With this background, an initial attempt in the form of the current research aspect entitled "Comparison of Reduced P Application and Supplemental Enhancement of Nitrogen $(\mathrm{N})$ and Zinc ( $\mathrm{Zn})$ on their Availability and Yield of Rice Crop (Oryza sativa L.) in High-P Soil was undertaken.

\section{Materials and Methods}

Different experiments are carried out and materials and methods employed to achieve the objective of this investigation.1) Development of different P- fertility regimes of the selected Soil. 2) Availability of Nitrogen and zinc in a soil with different Pfertility regimes and contact periods. 3) Effect of different supplemental doses of $\mathrm{N}$ and $\mathrm{Zn}$ on yield of rice crop in a high $P$ soil. Twenty five soil samples from different fields of College Farm, ANGRAU, Hyderabad and Directorate of Rice Research, Hyderabad were collected and analyzed for available $\mathrm{P}_{2} \mathrm{O}_{5}$. One soil having low available $\mathrm{P}_{2} \mathrm{O}_{5}\left(<23 \mathrm{~kg} \mathrm{P}_{2} \mathrm{O}_{5}\right.$ ha $^{-1}$ ) (Muhr et al., 1965) was selected to employ in incubation study of experiment no: 2. The bulk soil sample collected from different spot of selected field was processed and final available $\mathrm{P}_{2} \mathrm{O}_{5}$ was once again determined to ascertain the low status of 
available $\mathrm{P}_{2} \mathrm{O}_{5}$ to be employed in the incubation study. The physico- chemical characteristics of the soil was analyzed following standard procedures (Tandon, 1993; Linsay et al., 1978) and given in table 1. From the $\mathrm{P}$ - fixation characteristic curve, it was found that there is a need to determine precise value of $\mathrm{P}$-fixation to develop different $\mathrm{P}$ fertility regimes of same soil. The classification of low, medium and high categories was based on Muhr et al., (1963). The v. high and v.v high regimes were arbitrarily fixed as there is no such soil classification available in the literature in order to mimic the $\mathrm{v}$. high status of $\mathrm{P}-$ accumulated soil. Therefore, $\mathrm{P}$ - fixation characteristics of the soil was once again determined by employing $\mathrm{P}$ solution in the range of 10 to $50 \mathrm{ppm} P$ solution with narrow intervals of $5 \mathrm{ppm}$. The quantities of $\mathrm{P}$ to be added to arrive at different $\mathrm{P}$ - fertility regimes were found from the final graph (Fig. 1 and 2). Accordingly, different $\mathrm{P}$ - fertility regimes of medium (23- $56 \mathrm{~kg} \mathrm{P}_{2} \mathrm{O}_{5} \mathrm{ha}^{-1}$ ), High (56- 80 kg $\mathrm{P}_{2} \mathrm{O}_{5}$ ha $^{-1}$ ), Very. High (80- $110 \mathrm{~kg} \mathrm{P}_{2} \mathrm{O}_{5}$ ha $^{-}$ $\left.{ }^{1}\right)$ and Very. Very High (>110 kg P $\mathrm{O}_{5} \mathrm{ha}^{-1}$ ) were made (Table 3 ). No P- solution was added to the original soil and is taken as such to designate it as low $\mathrm{P}$ - regime soil. The above treated soils were saturated with water, stirred well and left it for drying in laboratory at $70{ }^{0} \mathrm{C}$ in an oven. The soil thus obtained was grounded and analyzed for final available $\mathrm{P}_{2} \mathrm{O}_{5}$ to employ in incubation studies. Different treatments were employed in the incubation studies. Hundred grams of each of five P- fertility regime soils was taken in thirty plastic bottles. Different solutions of treatments (i.e. 3 levels of nutrients $\mathrm{x} 2$ replication $\mathrm{x} 5 \mathrm{P}$ - fertility regimes) were introduced into this soil as per the necessity. Samples were drawn from each set after 15, 30 and 45 days of contact period from same plastic bottles containing soil and analyzed for required nutrients. Treatments and replications were made so as to draw the samples for analysis after 15, 30 and 45 days of contact. Throughout the incubation periods the soil moisture was maintained at field capacity based on weight loss at an interval of 5 days. The details of the treatments are given below:

Levels of P fertility : $\quad 5$

Nutrient Studied $\quad: \quad 2(\mathrm{~N}$ and $\mathrm{Zn})$

P-Fertility regimes : $\quad 5$ : low $(<23 \mathrm{~kg}$ $\mathrm{P}_{2} \mathrm{O}_{5} \mathrm{ha}^{-1}$ ), medium (23- $56 \mathrm{~kg} \mathrm{P}_{2} \mathrm{O}_{5} \mathrm{ha}^{-1}$ ), high (56- $\left.80 \mathrm{~kg} \mathrm{P}_{2} \mathrm{O}_{5} \mathrm{ha}^{-1}\right)$, v. high (80- $110 \mathrm{~kg}$ $\mathrm{P}_{2} \mathrm{O}_{5}$ ha $^{-1}$ ), v.v high (> $\left.110 \mathrm{~kg} \mathrm{P}_{2} \mathrm{O}_{5} \mathrm{ha}^{-1}\right)$

Levels of Nutrient studied : $\mathrm{N}: 100,125$ and $150 \%$ RDZn: 25, 50 and $100 \%$ RDZn

No. of P- levels $\quad$ : $\quad 2(100 \%$ RDP and $70 \% \mathrm{RDP}$ )

No. of contact periods : $\quad 3(15,30$ and 45 days)

Replications : 2

Design of experiment : $\quad$ CRD

The details of $100 \%$ RDF and $25 \%$ recommended doses of supplemental nutrients are given below:

$100 \% \mathrm{RDF} \quad: \quad 120 \mathrm{~kg} \mathrm{~N}+60$

$\mathrm{kg} \mathrm{P}_{2} \mathrm{O}_{5}+40 \mathrm{~kg} \mathrm{~K}_{2} \mathrm{O}$

$25 \%$ Excess $\mathrm{N} \quad: \quad 30 \mathrm{~kg} \mathrm{~N}$

$25 \% \mathrm{Zn} \quad: \quad 6 \mathrm{~kg}$ of $\mathrm{ZnSO}_{4}$

(i.e. $1 / 4$ of $25 \mathrm{~kg} \mathrm{ZnSO}_{4} /$ ha recommended for rice crop)

At the end of each contact period, samples were drawn from the treated soil of each set to analyze $\mathrm{N}$ and $\mathrm{Zn}$ following standards methods. A pot culture experiment was conducted in net house at ARI, Rajendranagar, Hyderabad during kharif 2013 to study the effect of different supplemental doses of nutrients ( $\mathrm{N}$ and $\mathrm{Zn}$ ) on yield of Rice crop in a High $\mathrm{P}$ soil under varying levels of $\mathrm{P}$ application. One soil having high $\mathrm{P}$ availability was selected from twenty five soil samples collected and analyzed. The physiochemical properties of the soil are given in table 2 . The potting of soil was done taking six 
(6) kilograms of each of selected bulk and the processed soil was filled in a plastic buckets with a hole made at the bottom. The following treatments were imposed in this experiment (Table 1).

No. of supplemental Nutrients: 9

Levels of $\mathrm{P}$

RDP \& $70 \%$ RDP)

Total Treatments

Replication

Total no. of Pots

Design of experiment

RDF of crop :

$\mathrm{P}_{2} \mathrm{O}_{5}: \mathrm{K}_{2} \mathrm{O} \mathrm{kg} \mathrm{ha}{ }^{-1}$ )

RD Zn of crop : $\quad 25 \mathrm{~kg} \mathrm{ZnSO}_{4} \mathrm{ha}^{-1} /$ crop.

\section{Results and Discussion}

The results obtained in this investigation are presented below followed by discussion.

The P- fixation characteristic curve obtained following the standard procedure of Ghosh et al., (1983) is given in Figure 1. It was noticed from the figure that the actual P-fixation was not very sharp as the concentration employed became very wide at higher levels. Therefore, from the graph a range of 10 to $50 \mathrm{ppm} P$ solution were once again employed with small intervals @ of 5 ppm each to obtain the inflexion point from where $\mathrm{P}$ - fixation became constant. The P- fixation characteristics of the soil employed with the desire concentration is given in Figure 2.

From the graph it was clear that the P- fixation capacity of the low P- soil selected for developing different $\mathrm{P}$ - regimes was $72 \%$. The $\mathrm{P}$ - fixation as well as the $\mathrm{P}$ - extraction curves was used to determine the approximate levels of P- availability status of the soil with the known addition of the soil duly allowing for the P- fixation. The following are the different levels of concentration of P- added (Table 3) and the P-availability of such soil after three
(3) cycles of alternate wetting and drying under laboratory condition.

This soil of different P-fertility regimes developed @ $3 \mathrm{~kg}$ for each regime was employed in the incubation study.

Availability of Nitrogen under varying Pfertility regimes with varying contact periods

\section{Effect of P-fertility regimes}

The availability of Nitrogen increased significantly from 219 to $311 \mathrm{~kg} \mathrm{~N} /$ ha as the P-fertility of the same soil increased from low $\left(<23 \mathrm{~kg} \mathrm{P}_{2} \mathrm{O}_{5} \mathrm{ha}^{-1}\right)$ to very high level $(>110$ $\mathrm{kg} \mathrm{P}_{2} \mathrm{O}_{5} / \mathrm{ha}$ ) over $\mathrm{N}$ and incubation period levels.

\section{Effect of varying levels of Nitrogen}

The available nitrogen increased significantly from 223 to $299 \mathrm{~kg}$ as the added $\mathrm{N}$ to soil was increased from $100 \% \mathrm{RDN}$ to $150 \% \mathrm{RDN}$.

\section{Effect of Contact period}

The available nitrogen in the soil increased significantly as the contact period of added nitrogen increased from 15 to 45 days over Pfertility regimes and levels of $\mathrm{N}$.

\section{Interaction of P- fertility $x$ Nutrient levels}

The interaction effect of P Fertility x Nutrient levels on extracted available $\mathrm{N}$ in the soil was significant. At any given level of added $\mathrm{N}$ (100 or 125 or $150 \%$ RDN), the highest available nitrogen was found to be in the soil with highest $\mathrm{P}$-fertility regime.

\section{Interaction of P-fertility $\mathrm{x}$ Contact period}

Data in table 4 indicated that highest $\mathrm{N}$ availability was noticed at 45 days of contact 
periods in the soil with highest P-fertility regime.

\section{Interaction of $\mathrm{N}$ levels $\mathrm{x}$ contact period}

The nitrogen availability in soil was significantly affected by the interaction of $\mathrm{N}$ levels x Contact period. Application of $150 \%$ RDN to soil after 45 days of contact period resulted in highest Nitrogen estimation over $\mathrm{P}$ fertility regimes.

Interaction of $P$ - fertility $x$ levels $x$ Contact period

It was found to be non-significant.

Availability of Zinc under different Pfertility regimes with varying contact periods

\section{Effect of P-fertility regimes}

The DTPA extractable zinc decreased significantly with increasing phosphorus fertility level.

The decreasing was noticed from low phosphorus to high phosphorus level (3.28 to $2.66 \mathrm{mg} / \mathrm{kg}$ ). Subsequent enhancement in phosphorus fertility resulted in statistically similar zinc extractability in the range of 2.55 to $2.68 \mathrm{mg} / \mathrm{kg}$.

\section{Effect of varying level of Zinc}

Applicability of the increasing levels of Zinc from 25 to $100 \% \mathrm{RD} \mathrm{Zn}$ significantly increased the DTPA Zn extraction from 2.57 to $3.07 \mathrm{mg} / \mathrm{kg}$ (over P-fertility and Contact period) as given in Table 5.

\section{Effect of Contact period}

The DTPA extractable Zinc decreased significantly from 2.87 (mean of 2.6, 2.9 and 3.12 ) to $2.66 \mathrm{mg} / \mathrm{kg}$ with increasing contact from 15 to 30 days. However, the DTPA zinc increased significantly and reduced to original status $(2.96 \mathrm{mg} / \mathrm{kg})$ by the time the contact period increased to 45 days.

\section{Interaction of P-fertility x Zinc levels}

Interaction effect of P-fertility x Zinc levels was found to be non-significant.

\section{Interaction of P-fertility $\mathbf{x}$ Contact period}

It was also found to be non-significant.

Interaction of P-fertility $x$ Zinc levels $x$ Contact period

It was also found to be non-significant.

Effect of different supplemental doses of nutrients and $P$ levels on paddy grain and straw yield in a high $P$ soil

These result as indicated in Table 6 shown that supplemental enhancement of Nitrogen (T2) recorded highest paddy grain yield and straw yield of $13.0 \mathrm{gm} \mathrm{pot}^{-1}$ and $15.9 \mathrm{gm} \mathrm{pot}^{-1}$ respectively.

The application of RDF-NK + 25\% RD Zinc (T3) recorded paddy grain yield and straw yield of $12.7 \mathrm{gm} \mathrm{pot}^{-1}$ and $15.6 \mathrm{gm} \mathrm{pot}^{-1}$ respectively whereas amongst the three (3) treatments the application of $100 \%$ RDF of NK (T1) had shown less paddy grain yield and straw yield of $12.1 \mathrm{gm} \mathrm{pot}^{-1}$ and $14.6 \mathrm{gm} \mathrm{pot}^{-1}$. On the other hand, reduced application of $\mathrm{P}(\mathrm{i}$, e $70 \%$ RDP) significantly reduced the paddy grain yield over different treatments as compared to the recommended dose of P (i.e. $100 \%$ RDP).

These result indicated that in a high $\mathrm{P}$ soil, there is a possibilities to improve the yield of paddy crop by additionally supplying of $\mathrm{N}$ in excess of the recommended dose. 
Table.1 Different treatments employed in the experiment

\begin{tabular}{|l|l|l|}
\hline \multirow{2}{*}{ S.No } & \multicolumn{1}{|c|}{ Set-I } & \multicolumn{1}{c|}{ Set-II } \\
\hline $\mathbf{1}$ & \multicolumn{1}{|c|}{ With 100 \% RDP } & With ST based Phosphorus (70 \% RDP) \\
\hline $\mathbf{2}$ & RDly RDF of NPK (100 \% RDP) & RD-NK + STBP ( i.e 70\% RDP) \\
\hline $\mathbf{5}$ & RDF-NPK + 25\% Excess N & RD-NK + STBP + 25\% Excess N \\
\hline
\end{tabular}

Table.2 Salient characteristics of soil used in incubation study and pot culture experiment

\begin{tabular}{|c|c|c|c|}
\hline S No. & Soil characters & $\begin{array}{l}\text { Soil used for } \\
\text { incubation study }\end{array}$ & $\begin{array}{l}\text { Soil used for pot } \\
\text { culture experiment }\end{array}$ \\
\hline I) & Physical properties & & \\
\hline \multirow[t]{5}{*}{ a) } & Mechanical composition & & \\
\hline & i) Sand (\%) & 66 & 38 \\
\hline & ii) Silt (\%) & 11 & 27 \\
\hline & iii) Clay (\%) & 23 & 35 \\
\hline & iv) Textural class (USDA) & Clay loam & Silty clay loam \\
\hline II) & Physico-chemical properties & & \\
\hline a) & $\begin{array}{l}\text { Soil reaction }(\mathrm{pH})(1: 2.5 \text { soil : water } \\
\text { suspension) }\end{array}$ & 7.91 & 8.01 \\
\hline \multirow[t]{2}{*}{ b) } & $\begin{array}{l}\text { Electrical conductivity }(1: 2.5 \text { soil : water } \\
\text { extract })\left(\mathrm{dS} \mathrm{m}^{-1}\right)\end{array}$ & 1.11 & 0.94 \\
\hline & Water Holding capacity (WHC at $33 \mathrm{KPa})(\%)$ & 30.69 & \\
\hline III) & Available nutrients & & \\
\hline a) & Nitrogen $\left(\mathrm{kg} \mathrm{ha}^{-1}\right)$ & 252 & 296 \\
\hline b) & Phosphorus $\left(\mathrm{kg} \mathrm{P}_{2} \mathrm{O}_{5} \mathrm{ha}^{-1}\right)$ & 16 & 89 \\
\hline c) & Potassium $\left(\mathrm{kg} \mathrm{K}_{2} \mathrm{O} \mathrm{ha}^{-1}\right)$ & 343 & 361 \\
\hline d) & Sulphur $\left(\mathrm{mg} \mathrm{kg}^{-1}\right)$ & 10.4 & 12 \\
\hline e) & Boron $\left(\mathrm{mg} \mathrm{kg}^{-1}\right)$ & 4.2 & 2.6 \\
\hline f) & Free Calcium Carbonate (\%) & 1.95 & 1.8 \\
\hline \multirow[t]{5}{*}{ g) } & Available Micronutrients (ppm) & & \\
\hline & Cupper $(\mathrm{Cu})$ & 6.21 & 4.72 \\
\hline & Manganese (Mn) & 4.11 & 3.22 \\
\hline & Iron $(\mathrm{Fe})$ & 10.22 & 14.58 \\
\hline & Zinc (Zn & 2.12 & 1.66 \\
\hline
\end{tabular}


Table.3 Details of development of different P- fertility regimes using P- fixation Curve

\begin{tabular}{|c|c|c|c|c|}
\hline $\begin{array}{l}\text { Desired P- } \\
\text { fertility } \\
\text { Regimes }\end{array}$ & $\begin{array}{l}\text { Desired } \\
\text { availability of } \\
\mathrm{kg} \mathrm{P}_{2} \mathrm{O}_{5} / \mathrm{ha} \\
\text { for experiment }\end{array}$ & $\begin{array}{l}\text { Amount of } P \\
(\mu \mathrm{g} / \mathrm{g}) \text { added } \\
\text { using fig. } 2\end{array}$ & $\begin{array}{c}\text { Amount of kg } \\
\mathrm{P}_{2} \mathrm{O}_{5} / \text { ha added } \\
\text { to get desired } \mathrm{P} \text { - } \\
\text { regime }\end{array}$ & $\begin{array}{c}\text { Final available } \\
\mathrm{kg} \mathrm{P}_{2} \mathrm{O}_{5} / \text { ha after } \\
3 \text { cycles of } \\
\text { wetting and } \\
\text { drying }\end{array}$ \\
\hline $\begin{array}{l}\text { Low } \quad<\quad 23 \\
\left.\operatorname{kgP}_{2} \mathrm{O}_{5} / \mathrm{ha}\right)\end{array}$ & $\begin{array}{l}\text { Used as such } \\
\left(16 \mathrm{kgP}_{2} \mathrm{O}_{5} / \mathrm{ha}\right)\end{array}$ & Used as such & Used as such & Used as such \\
\hline $\begin{array}{l}\text { Medium (23-56 } \\
\left.\mathrm{P}_{2} \mathrm{O}_{5} / \mathrm{ha}\right)\end{array}$ & 45 & 26.0 & 133 & 40 \\
\hline $\begin{array}{l}\text { High (56- } 80 \\
\left.\mathrm{P}_{2} \mathrm{O}_{5} / \mathrm{ha}\right)\end{array}$ & 70 & 40.2 & 206 & 63 \\
\hline $\begin{array}{l}\text { V. High (80- } \\
\left.\text { 110P }_{2} \mathrm{O}_{5} / \mathrm{ha}\right)\end{array}$ & 100 & 57.2 & 293 & 102 \\
\hline $\begin{array}{l}\text { V.V High } \\
\left.110 P_{2} \mathrm{O}_{5} / \mathrm{ha}\right)\end{array}$ & 125 & 71.9 & 368 & 128 \\
\hline
\end{tabular}

Fig.1 P- Fixation characteristic curve of a low-P soil employed for development of different Pfertility regimes

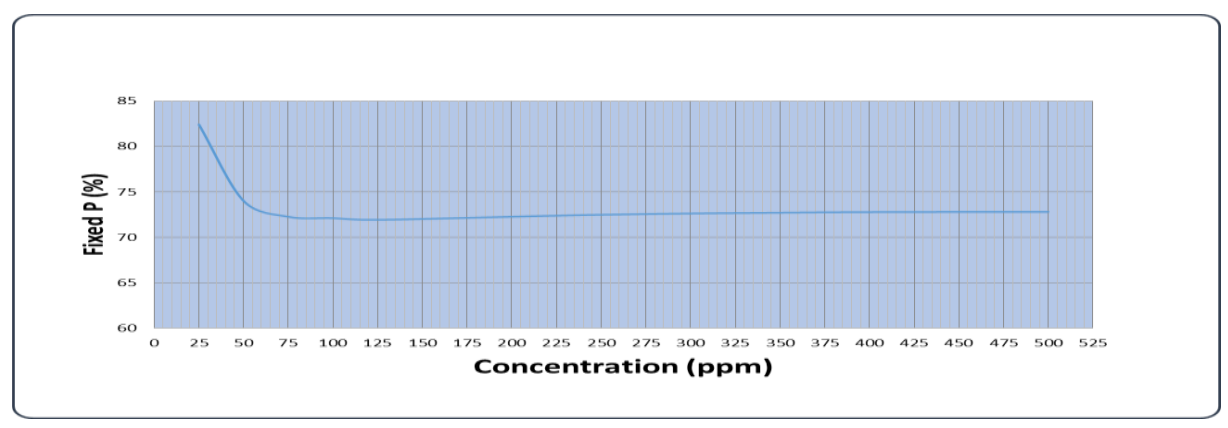

Fig.2 Detail P- Fixation curve obtained with selected range of $\mathrm{P}$ application

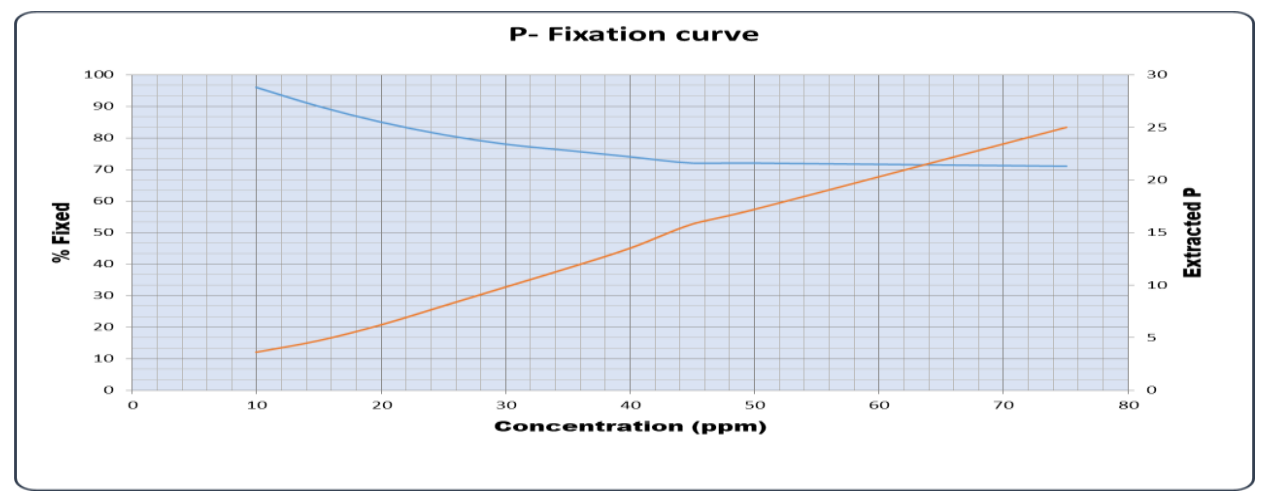


Int.J.Curr.Microbiol.App.Sci (2019) 8(10): 1102-1112

Table.4 Effect of varying P- fertility and Nitrogen levels on Nitrogen availability at different contact periods:

\begin{tabular}{|c|c|c|c|c|c|c|c|c|c|c|c|c|c|}
\hline \multirow{3}{*}{$\begin{array}{l}\text { P-Fertility } \\
\text { levels }\end{array}$} & \multicolumn{13}{|c|}{ Nutrient Levels } \\
\hline & \multicolumn{4}{|c|}{$100 \%$ RDN } & \multicolumn{4}{|c|}{$125 \% \mathrm{RDN}$} & \multicolumn{4}{|c|}{$150 \%$ RDN } & \multirow{2}{*}{$\begin{array}{l}\text { Grand } \\
\text { Mean }\end{array}$} \\
\hline & $15 \mathrm{D}$ & $30 \mathrm{D}$ & $45 \mathrm{D}$ & Mean & $15 \mathrm{D}$ & $30 \mathrm{D}$ & $45 \mathrm{D}$ & $\underset{\mathbf{n}}{\text { Mea }}$ & $15 \mathrm{D}$ & $30 \mathrm{D}$ & $45 \mathrm{D}$ & Mean & \\
\hline $\begin{array}{l}\text { Low } \\
\left(16 \mathrm{~kg} \mathrm{P}_{2} \mathrm{O}_{5} / \mathrm{ha}\right)\end{array}$ & 150 & 178 & 186 & 182 & 192 & 226 & 231 & 228 & 220 & 257 & 251 & 254 & 219 \\
\hline $\begin{array}{l}\text { Medium } \\
\left(40 \mathrm{P}_{2} \mathrm{O}_{5} / \mathrm{ha}\right)\end{array}$ & 160 & 184 & 198 & 191 & 198 & 231 & 245 & 238 & 231 & 264 & 282 & 273 & 230 \\
\hline $\begin{array}{l}\text { High } \\
\left(63 \mathrm{P}_{2} \mathrm{O}_{5} / \mathrm{ha}\right)\end{array}$ & 175 & 211 & 217 & 214 & 210 & 251 & 260 & 256 & 249 & 284 & 291 & 288 & 248 \\
\hline $\begin{array}{l}\text { V. High } \\
\left(102 \mathrm{P}_{2} \mathrm{O}_{5} / \mathrm{ha}\right)\end{array}$ & 200 & 231 & 248 & 240 & 225 & 276 & 284 & 280 & 265 & 316 & 319 & 318 & 273 \\
\hline $\begin{array}{l}\text { V.V High } \\
\left(128 \mathrm{P}_{2} \mathrm{O}_{5} / \mathrm{ha}\right)\end{array}$ & 243 & 274 & 301 & 288 & 251 & 314 & 315 & 315 & 311 & 359 & 364 & 362 & 314 \\
\hline Mean & 186 & 216 & 230 & 223 & 215 & 260 & 267 & 263 & 255 & 296 & 301 & 299 & 257 \\
\hline Factor & \multicolumn{2}{|c|}{$\begin{array}{l}\text { P-Fertility } \\
\text { levels (PF) }\end{array}$} & \multicolumn{2}{|c|}{$\begin{array}{l}\text { Nutrient levels } \\
\text { (NL) }\end{array}$} & \multicolumn{2}{|c|}{$\begin{array}{c}\text { Contact } \\
\text { periods }(\mathrm{CP})\end{array}$} & \multicolumn{2}{|c|}{ PF X NL } & \multicolumn{2}{|c|}{ PF X CP } & \multicolumn{2}{|c|}{ NL X CP } & $\begin{array}{c}\text { PF X } \\
\text { NL X } \\
\text { CP }\end{array}$ \\
\hline $\operatorname{SEm}( \pm)$ & \multicolumn{2}{|c|}{2.35} & \multicolumn{2}{|c|}{1.82} & \multicolumn{2}{|c|}{1.82} & \multicolumn{2}{|c|}{4.08} & \multicolumn{2}{|c|}{4.08} & \multicolumn{2}{|c|}{3.16} & NS \\
\hline CD (5\%) & \multicolumn{2}{|c|}{4.74} & \multicolumn{2}{|c|}{3.67} & \multicolumn{2}{|c|}{3.67} & \multicolumn{2}{|c|}{8.22} & \multicolumn{2}{|c|}{8.22} & \multicolumn{2}{|c|}{6.37} & NS \\
\hline
\end{tabular}


Table.5 Effect of varying P- fertility and Zinc levels on Zinc availability at different contact periods:

\begin{tabular}{|c|c|c|c|c|c|c|c|c|c|c|c|c|c|}
\hline \multirow{2}{*}{$\begin{array}{l}\text { P-Fertility } \\
\text { levels }\end{array}$} & \multicolumn{12}{|c|}{ Nutrient Levels } & \multirow{2}{*}{$\begin{array}{l}\text { Grand } \\
\text { Mean }\end{array}$} \\
\hline & \multicolumn{4}{|c|}{$25 \%$ RDZn } & \multicolumn{4}{|c|}{$50 \%$ RDZn } & \multicolumn{4}{|c|}{$100 \%$ RDZn } & \\
\hline $\begin{array}{l}\text { Low } \\
(16 \mathrm{~kg} \\
\left.\mathrm{P}_{2} \mathrm{O}_{5} / \mathrm{ha}\right)\end{array}$ & 2.73 & 2.51 & 2.79 & 2.68 & 3.00 & 2.94 & 3.21 & 3.05 & 3.30 & 3.11 & 3.39 & 3.27 & 3.00 \\
\hline $\begin{array}{l}\text { Medium } \\
\left(40 \mathrm{P}_{2} \mathrm{O}_{5} / \mathrm{ha}\right)\end{array}$ & 2.41 & 2.28 & 2.57 & 2.42 & 2.76 & 2.59 & 2.84 & 2.73 & 2.89 & 2.64 & 2.97 & 2.83 & 2.66 \\
\hline $\begin{array}{l}\text { V. High } \\
\left(102 \mathrm{P}_{2} \mathrm{O}_{5} / \mathrm{ha}\right)\end{array}$ & 2.45 & 2.12 & 2.61 & 2.39 & 2.70 & 2.58 & 2.75 & 2.68 & 3.01 & 2.79 & 3.10 & 2.97 & 2.68 \\
\hline $\begin{array}{l}\text { V.V High } \\
\left(128 \mathrm{P}_{2} \mathrm{O}_{5} / \mathrm{ha}\right)\end{array}$ & 4.99 & 7.80 & 11.09 & 2.45 & 5.22 & 8.11 & 11.30 & 2.77 & 5.40 & 8.20 & 11.48 & 2.95 & 2.72 \\
\hline
\end{tabular}


Table.6 Effect of different supplemental doses of nutrients and P levels on paddy grain and straw yield in a high P soil

\begin{tabular}{|c|c|c|c|c|c|c|c|}
\hline \multirow[t]{2}{*}{ T. No } & \multirow[t]{2}{*}{ Treatments } & \multicolumn{3}{|c|}{ Grain yield $\left(\mathrm{gm} \mathrm{pot}^{-1}\right)$} & \multicolumn{3}{|c|}{ Straw yield $\left(\mathrm{gm} \mathrm{pot}^{-1}\right)$} \\
\hline & & $\begin{array}{l}100 \% \\
\text { RDP }\end{array}$ & $\begin{array}{l}70 \% \\
\text { RDP }\end{array}$ & Mean & $\begin{array}{l}100 \% \\
\text { RDP }\end{array}$ & $\begin{array}{l}70 \% \\
\text { RDP }\end{array}$ & Mean \\
\hline T1 & $\begin{array}{l}100 \% \text { RDF of } \\
\text { NK }\end{array}$ & 12.5 & 11.8 & 12.1 & 14.9 & 14.2 & 14.6 \\
\hline $\mathbf{T 2}$ & $\begin{array}{l}\text { RDF-NK + 25\% } \\
\text { Excess Nitrogen }\end{array}$ & 13.7 & 12.3 & 13.0 & 16.6 & 15.1 & 15.9 \\
\hline \multirow[t]{5}{*}{ T3 } & $\begin{array}{l}\text { RDF-NK + 25\% } \\
\text { RD Zinc }\end{array}$ & 13.9 & 11.4 & 12.7 & 17.1 & 14.1 & 15.6 \\
\hline & Mean & 13.7 & 12.5 & 13.1 & 16.7 & 15.1 & 15.9 \\
\hline & & $\begin{array}{l}\text { Treatm } \\
\text { ents (T) }\end{array}$ & P- Levels & T X P & $\begin{array}{l}\text { Treatme } \\
\text { nts (T) }\end{array}$ & P-Levels & T X P \\
\hline & $\operatorname{SEm}( \pm)$ & 0.30 & 0.14 & 0.44 & 0.36 & 0.17 & 0.50 \\
\hline & $\mathrm{CD}(\mathrm{P}=0.05)$ & 0.64 & 0.30 & NS & 0.75 & 0.35 & NS \\
\hline
\end{tabular}

The recommendation to apply nutrients either in excess or when they are present in sufficient quantities (above critical limits) is not generally accepted practiced. However, the current study indicated that in a high $\mathrm{P}$ soil additional supply of nutrients beyond current recommendation is required and is helpful in improving the yield.

On the other hand, Tabar (2012) reported highest yield of rice when highest levels of 150 $\mathrm{kg} \mathrm{N}$ and $90 \mathrm{~kg} \mathrm{P}$ fertilizer was added. Once again, these experiments were not conducted in a high $\mathrm{P}$ soil. In this experiment, $\mathrm{Zn}$ was also supplied (25\% RD Zn) though it was not required as per the critical limits in the soil. However, not much advantage was obtained due to additional $\mathrm{Zn}$ supply over and above 100 $\%$ recommended dose of fertilizer. On the other hand, Sri Ramya (2014) while working with zinc requirement for high $\mathrm{P}$ soil reported that about 7 per cent of higher yield of paddy can be realize in high $\mathrm{P}$ soil upon application of 12.5 $\mathrm{kg} \mathrm{ZnSO}_{4} \mathrm{ha}^{-1}$ even when the high $\mathrm{P}$ soil contain DTPA $\mathrm{Zn}$ of about $0.6 \mathrm{mg} \mathrm{Zn} \mathrm{kg} \mathrm{soil}{ }^{-1}$. Das et al., (2005) suggested the synergistic interaction between phosphorus and zinc on their availability in soil in relation to their contents in Stevia (Stevia rebaudiana). In the present study the additional yields obtain due to supplementation with zinc to high $\mathrm{P}$ soil was only $5 \%$. These results points out that for a high $\mathrm{P}$ soil, though sufficient available nutrient (current critical limits) are present, additional supplementation of $\mathrm{N}$ would help in realizing higher yield in paddy crop in a high- $\mathrm{P}$ soil.

On the other hand, reduced application of $\mathrm{P}$ (i, e $70 \%$ RDP) significantly reduced the paddy grain yield over different treatments. Surendra babu et al., (2008) and Sri Ramya (2014) reported similar yield of paddy in a high- $\mathrm{P}$ soil even when $\mathrm{P}$ application was reduced by 25 per cent in high- $\mathrm{P}$ soil. The extent of benefits due to different supplemental nutrients both under 100 and 70 per cent RDP is shown in Table 6.

In conclusion, it can be stated that for a high- $\mathrm{P}$ regime soil, the addition of different nutrient in small quantities of $\mathrm{N}$ and $\mathrm{Zn}$ as supplemental doses even when they are beyond recommendation levels this help in increasing the yield of paddy grain and straw yield.

\section{References}

Anonymous. 2010. Annual Report of Radio tracer Laboratory, (2008- 2010), ARI, ANGRAU, HYD-30. 
Das, K., Dang, R., Shivananda, T. N and Sur, P. 2005. Interaction effect between phosphorus and zinc on their availability in soil in relation to their contents in Stevia (Stevia rebaudiana). The Scientific World Journal. 5: 490- 495.

Ghosh, A. B., Bajaj, J. C., Rehanul, H and Singh, D. 1983. Soil and water testing methods (A laboratory manual). Soil Testing Laboratory, Division of Soil Science and Agricultural Chemistry, IARI, New Delhi.

Gill, M. A., Kanwal, S., Aziz, $\mathrm{T}$ and Rahmatullah. 2004. Differences in phosphorus-zinc interaction among Sunflower (Helianthus annuus L.), Brassica (Brassica napus L.) and Maize (Zea mays L.). Pak. J Agri. Sci. 41(1-2): 29- 34.

Haden, V. R., Ketterings, Q.M and Kahabka, J. E. 2007. Factors Affecting Change in soil test phosphorus following manure and fertilizer application. Soil Sci. Soc. Am. J. 71: 1225- 1232.

Holford, I. C. R. 1997. Soil phosphorus; its measurement, and its uptake by plants. Aust J. Soil Res. 35: 227- 239.

Hoque, M. A., Aktar, M., Chowdhury, M. A. K and Chowdhury, M. A. H. 2010. Influence of nitrogen and phosphorus on nutrient contents and their uptake by aromatic rice $\mathrm{cv}$. BRRI dhan34. Int. J. BioRes. 2(7): 19- 23.

Imitiaz, M and Alloway, B. J. 2006. Zinc tolerance in wheat cultivars as affected by varying levels of phosphorus. Communications in Soil Science and Plant Analysis. 37: 1689-1702.
Linsay, W. L and Norwell, W. A. 1978. Development of DTPA soil test for zinc, iron, manganese and copper. Soil Science Society of America Journal. 42: 421- 428.

Muhr, G. R., Datta, N. P., Leley, V. K and Donahu, R. L. 1963. Soil Testing in India. II Edn. United States Agency for International Development Mission to India, New Delhi, 118.

Nambiar, K.K.M. 1994. Soil fertility and crop productivity under long- term fertilizer use in India. Indian Council of Agricultural Research Publication, New Delhi.

Sri Ramya. 2014. Zinc requirement to rice in High- $P$ soils varying in their native available Zinc status. M.Sc (Ag) Thesis. Acharya N. G Ranga Agricultural University, Rajendranagar, Hyderabad.

Surendra, B. P., Venkata, R. P and Madhavi, A. 2008. Phosphorus requirement to rice crop in High- P soil. Annual Report 200708. Radio Tracer Laboratory, ANGRAU, Hyderabad.

Surendra, B. P and Patnaik, M. C. 2013. In Annual report of AICRP on Micronutrient 2012-2013, ANGRAU, Hyderabad.

Tabar, Y. S. 2012. Effect of nitrogen and phosphorus fertilizer on growth and yield of Rice (Oryza sativa L.). International Journal of Agronomy and Plant Production. 3 (12): 579- 584.

Tandon, H.L.S. 1993. Methods of Analysis of soils, plants, water and fertilizer (ed.). Fertilizer Development and Consultation Organization, New Delhi.

\section{How to cite this article:}

Maishnam Anand Singh, P. Surendra Babu and Chandini Patnaik, M. 2019. Comparison of Reduced P Application and Supplemental Enhancement of Nitrogen (N) and Zinc ( $\mathrm{Zn})$ on their Availability and Yield of Rice (Oryza sativa L.) Crop in High- P Soil. Int.J.Curr.Microbiol.App.Sci. 8(10): 1102-1112. doi: https://doi.org/10.20546/ijcmas.2019.810.129 